How To (Not) Be King : Negotiating the Limits of Power Within the Assyrian Political Hierarchy

\title{
Zaia, Shana
}

2018-10

Zaia, S 2018 , ' How To (Not) Be King : Negotiating the Limits of Power Within the Assyrian

Political Hierarchy ' , Journal of Near Eastern Studies , vol. 77 , no. 2 , pp. 207-217 . https://doi.org/10.1086/699284

http://hdl.handle.net/10138/306604

https://doi.org/10.1086/699284

cc_by

publishedVersion

Downloaded from Helda, University of Helsinki institutional repository.

This is an electronic reprint of the original article.

This reprint may differ from the original in pagination and typographic detail.

Please cite the original version. 


\title{
How To (Not) Be King: Negotiating the Limits of Power within the Assyrian Hierarchy
}

\author{
SHANA ZAIA, University of Helsinki*
}

\section{Introduction}

After Shalmaneser III's (858-824 BC) otherwise strong reign ended in rebellions, Assyria's kings seem to have suffered a decline in power. Although Shalmaneser III's immediate successor, Šamšī-Adad V (823-811 BC), restored the sovereignty of Assyrian kingship to some extent after those rebellions, strong, centralized authority eluded subsequent kings until the reign of Tiglath-pileser III (744-727 BC), when Assyria's imperial phase began. The intervening period, from 823 to $745 \mathrm{BC}$, was marked by a rise in the number of internal rebellions and power struggles, an apparent contraction of Assyrian hegemony, and a marked decrease in the number of extant royal inscriptions. At the same time, Assyrian high officials (often called "magnates" in scholarly literature) appear to have gained remarkable power and authority. ${ }^{1}$ Power-

* This research was made possible by the Academy of Finland funded Center of Excellence: Changes in Sacred Texts and Traditions at the University of Helsinki, led by Martti Nissinen. I am grateful to Jamie Novotny, Seth Richardson, and the anonymous reviewers for their suggestions, comments, and corrections. Bibliographic abbreviations follow the Assyrian Dictionary of the University of Chicago (CAD) (Chicago: 1954-2010).

1 This period and these officials have recently been studied by Luis R. Siddall, The Reign of Adad-nīrārì III: An Historical and Ideological Analysis of An Assyrian King and His Times (Leiden, ful officials are known from other chapters of Assyrian history, but the relative weakness of the kings in this historical moment puts high officials into sharper focus within the royal inscriptions. ${ }^{2}$ In addition, that these

2013), but are also discussed in A. K. Grayson, "Assyrian Officials and Power in the Ninth and Eighth Centuries," State Archives of Assyria Bulletin 7 (1993); A. K. Grayson, "Assyria: Ashur-dan II to Ashur-Nirari V (934-745 B.C.)" in The Cambridge Ancient History, vol. 3/1 (Cambridge, 1982); Andreas Fuchs, "Der Turtān Šamšĩ-ilu und die große Zeit der assyrische Großen (830-746)," Die Welt des Orients 38 (2008); Karen Radner, "Royal DecisionMaking: Kings, Magnates, and Scholars" in The Oxford Handbook of Cuneiform Culture, ed. K. Radner and E. Robson (Oxford, 2011); Raija Mattila, The King's Magnates: A Study of the Highest Officials in the Neo-Assyrian Empire. State Archives of Assyria 11 (Helsinki, 2000); Stephanie Dalley, "Shamshi-ilu, Language and Power in the Western Assyrian Empire" in Essays on Syria in the Iron Age, ed. Guy Brunnes (Louvain, 2000); Mattias Karlsson, Relations of Power in Early Neo-Assyrian State Ideology, SANER 10 (Leiden, 2016).

${ }^{2}$ For example, the "kings" of Hanigalbat during the Middle Assyrian period, mentioned below, and Shalmaneser III's turtānu Dayyān-Ašsur, who led campaigns on behalf of the aging king (RIMA 3 A.0.102.14: 141-90). Karlsson, Relations of Power, 22021 also includes the Shalmaneser III-era officials Aššur-bēl-ka"'in (RIMA 3 A.0.102.17, though the dating is not certain), Šamašbēlu-ușur (RIMA 3 A.0.102.30), Iahalu (RIMA 3 A.0.102.2003), and Mutarriṣ-Aššur (RIMA 3 A.0.103.1, from the reign of ŠamšīAdad V), among others. This phenomenon was not restricted to Assyria, either; for instance, Babylonian officials are known to have left inscriptions of their own, such as on dedicatory daggers

[JNES 77 no. 2 (2018)] (c) 2018 by The University of Chicago. All rights reserved. 0022-2968/2018/7702-0004\$10.00. DOI: 10.1086/699284 
officials had increased autonomy is evidenced in that they left behind "royal-type" inscriptions - that is, inscriptions that were not commissioned by the king, but imitate the structure and content of standard royal inscriptions, such as chronicling the officials' military endeavors, building activities, or dedications - which is unprecedented in the extant Assyrian textual record. ${ }^{3}$ The corpus of texts commissioned by these of-

(Šamaš-killanni, ša rêšsi [“eunuch”] of Marduk-nādin-ahhêe, RIMB 2 B.2.6.2001), a stone weight (Napsamenni, servant of Mardukšāpik-zēri, RIMB 2 B.2.7.2001), a bronze arrow head and iron dagger (Mār-bīti-šuma-ibni and Ninurta-nādin-šumi, respectively, both sakrumaš-officials of Nabû-mukīn-apli, RIMB 2 B.6.1.2004-2005), a royal-type inscription about renovating the Ezida in Borsippa (Nabû-šuma-imbi, governor of Borsippa under Nabû-šuma-iškun, RIMB 2 B.6.14.2001), and several bronze situlae whose dates are not known (RIMB 2 B.6.0.2002-2004. Some officials became quite powerful; for instance, the short-lived king Nabû-nādin-zēri was deposed by the provincial official Nabû-šuma-ukinn (RIMB 2 B.6.16). Fuchs "Der Turtān": 108-14, additionally provides comparative data from other regions such as Mitanni and Carchemish and parallels can be found in the Elamite Sukkalmah period (Katrien de Graef, "Elamite kings, Sukkalmah period," in The Encyclopedia of Ancient History 2012: 1-2 with further bibliography, accessed June 2018 at: onlinelibrary.wiley.com/doi/10.1002/9781444338386. wbeah24069/pdf).

${ }^{3}$ My use of the term "royal-type" follows the definition of A. K. Grayson (RIMA 3: 200-201), who characterizes his selection as comprising "inscriptions written to commemorate their [i.e., the officials'] deeds, just like an Assyrian monarch. . . . Most of the texts have the form of royal inscriptions and therefore I have included them, whether or not the Assyrian king is actually mentioned." While scholars do not generally include her in discussions about the high officials of this period, Sammu-ramāt (the mother of Adadnērārî III) also seems to have had remarkable power during her son's reign, to the point that some scholars considered her to have been a co-regent; on this issue, see Siddall, Adad-nìrārī III, 86-100, Stephanie Dalley, "Semiramis in History and Legend," in Cultural Borrowings and Ethnic Appropriations in Antiquity, ed. Erich S. Gruen (Stuttgart, 2005), and Wolfgang Schramm, "War Semiramis assyrische Regentin?" Historia 21/4 (1972). The debate is centered on the fact that her name appears on several stelae along with Adadnērārī III's name, and she commissioned her own stele, which was found in the Assur Stelenreihen (RIMA 3 A.0.104.2001). Like the high officials, Sammu-ramāt did not take on royal titles beyond what was permitted for royal women: the stele she commissioned, the Pazarcik stele, and Bēl-tarși-ilumma's stele dedicated to Adadnērārī III and Sammu-ramāt call her MUNUs.é.GAL, "palace woman," and the first two texts give her genealogy based on her relationships to the kings, who are given titularies clearly associated with regency (RIMA 3 A.0.104.2001: 1-7, A.0.104.3: 1-7, 9, A.0.104.2002: 8-9). Moreover, Sammu-ramāt's name is given after the king's when the two appear together. Thus, even though the Pazarcik stele describes the queen mother crossing the Euphrates River with her son, a highly unusual addition to the text, she avoided openly transgressing the scribal conventions, much as the high officials did. ficials is fairly small, but nonetheless almost as large as that of the contemporary Assyrian kings. ${ }^{4}$ It is generally agreed that inscriptions of the high officials demonstrate unusual levels of independence from the king, both in the fact of their having commissioned inscriptions, and in the content, which sometimes includes campaigns and building accounts. Scholarship is still divided, however, regarding whether the high officials usurped the king's authority, thus contributing to the decline of Assyria during this period, or if power was intentionally split between the Assyrian king and his officials as a stabilizing response to royal weakness that actually maintained Assyrian influence. The latter is what Luis Siddall calls "the Maintenance Hypothesis." 5

Although she is a later figure, the queen mother Naqīa (Zakūtu) is a similar case: the wife of Sennacherib and mother of Esarhaddon, she commissioned a number of inscriptions during her son's reign (RINAP 4 2003-2010) but was also restricted to the MUNUS.É.GAL title even when her reports of constructing a palace for her son, in particular, mirrored Esarhaddon's own inscriptions quite closely, though they were not as elaborate (for instance, the invitations of the gods into the completed palace in RINAP 4 2003: iii 13'-22' and 1: vi 44-49). This is true also of Naqīa's treaty when compared to Esarhaddon's Succession Treaty (SAA 26 and 8). In general, royal women may have had similar approaches to self-representation as the officials. For further information about royal women's agency, see Saana Svärd, Women and Power in Neo-Assyrian Palaces, State Archives of Assyria Studies 23 (Helsinki, 2015).

4 "Royal-type" is determined by form and content and follows the divisions made in RIMA 3: 200-201. The officials' corpus comprises 24 texts, as compared to 35 royal inscriptions. In contrast, Shalmaneser III left behind 116 texts and Tiglath-pileser III has 64 extant texts (see RIMA 3: 5-170 and RINAP 1: 19-154, respectively). High officials with extant royal-type inscriptions include the following: Bēl-dayyānī, ša rêssi (1 text); Bēl-Ḩarran-bēlī-ușur, nāgir ekalli ("palace herald," l text); Bēl-tarși-ilumma, ša rêsi , tupšarru ("scribe"), and šaknu ("governor," 4 texts); Marduk-šarra-ușur (title uncertain, possibly granted a governorship, l text); Nabûšarra-ușur, ša ra ressi (1 text); Nergal-ēriš, ša rềsi ša šanu, and holder of a mazziz pānūtu, "courtiership" (6 texts); Nergal-ilāà, turtānu ("field marshal," l text); Pān-Aššur-lāmur, šaknu (1 text); Remanniilu, ša rēssi (1 text); and Šamšĩ-ilu, turtānu (7 texts). Other titles associated with Šamšĩ-ilu are included in the inscription discussed below. Both the royal and royal-type inscriptions discussed in this paper are edited in RIMA 3, with additional bibliography for nonroyal-type inscriptions (RIMA 3: 201). Translations provided in this article follow the RIMA editions.

${ }^{5}$ Siddall, Adad-nìrārī III, 128-32. Versions of this idea have been suggested in earlier scholarship as well: Amélie Kuhrt writes that "it is just as possible to argue that, although very powerful, the governors essentially maintained the Assyrian empire, by ensuring its survival in the areas which it had conquered in the course of the ninth century, and defending its frontiers. Significantly, the governors never pose as kings, they never take royal titles and they 
This study joins the ongoing conversation by seeking to show how high officials conceptualized and expressed their own role within the recognized political hierarchy and looking at the inscriptions they commissioned. ${ }^{6}$ This, in turn, can provide a new perspective from which to evaluate the historical circumstances of this period. A close examination of the language of the relevant "royal-type" inscriptions shows that these texts were modeled on those of the kings: standardized elements of the royal inscriptions such as titularies, invocations of gods, campaign and building accounts, curses, and blessings are all present in the corpus of texts by officials - though those of the high officials differ in significant ways. These differences reveal the officials' careful and consistent attempts to imitate motifs and epithets found in royal inscriptions without openly claiming royal authority or appropriating prerogatives reserved for kings, especially the royal relationship with the gods.

Two texts in particular have been at the heart of the debate about the independence of officials in this period. The first was found on stone lions at Til-Barsip (Tell Ahmar, Syria), also called Kār-Shalmaneser, and was commissioned by Šamšĩilu, who was turtānu for almost fifty years. ${ }^{7}$ The second inscription is on a stele found at Tell Abta (on the Wadi Tharthar, to the west of Mosul, Iraq), written by Bēl-Hुarran-bēlī-ușur, who was nāgir ekalli starting under Shalmaneser IV (782-773 вC). ${ }^{8}$ Both texts are monumental, either omitting the reigning king's name or referencing him

define their positions always within the framework of the Assyrian court hierarchy. Also, despite the severe problems that Assyria experienced, especially after Adad-nirari III's reign, when it was plagued by epidemics, famines, revolts and succession problems for almost forty years, it never lost control of the great gains it had made in the tenth and earlier ninth century" (The Ancient Near East, c. 3000-330 BC v. 2 [London, 1997], 492). See also Dalley, "Shamshi-ilu," 85: "that such men were viceroys, 'kings' who ruled with the full support of the Assyrian king, is now evident from an array of evidence."

${ }^{6}$ One should acknowledge that scribes and artists were key figures in the self-representation of these officials. Who the scribes were in these cases is unknown, but they were clearly familiar with royal conventions, as they were able to adapt or avoid them. Neither is it is known whether the officials themselves were literate; Bêl-tarși-ilumma is the only official in this case who has the title tupšarru.

7 RIMA 3: 231-33 (A.0.104.2010); Fuchs, "Der Turtān”: 78-90, 93-94.

${ }^{8}$ RIMA 3: 241-42 (A.0.105.2). Further information on these offices and translations can be found in Mattila Magnates, Fuchs, "Der Turtān": 61, and the respective entries in the PNA. only in passing, describe independent building projects, and (in the case of Šamšĩ-ilu) contains a military campaign that he leads; all of which some scholars have read as indicating a rejection of the king's ultimate authority. ${ }^{9}$ But this study will demonstrate that, although the officials utilized the established elements of royal inscriptions, they amended these conventions in their texts to negotiate their increased autonomy within the political hierarchy, avoiding direct claims on the Assyrian throne or language that was reserved for royalty. As a direct relationship with the gods was a defining feature of Assyrian kingship, this paper mainly addresses the connections of the officials with the divine as depicted in these texts. In particular, the following discussion focuses on titulary and divine election, invocations, divine endorsement of campaigns, and divine support of building projects. Examples from the inscriptions of the high officials are juxtaposed with the corresponding features in inscriptions by Assyrian kings who reigned immediately preceding and during this period to demonstrate the deliberateness with which high officials used language to approach, but not cross, the established ideological boundaries of their authority, even if their actual authority may have been greater. ${ }^{10}$

\section{Titulary and the Divine Election of Kings}

The reigning Assyrian king was considered the highest official of the god Aššr and the living connection between the mortal and divine worlds. ${ }^{11}$ Kings also

\footnotetext{
9 Grayson, "Assyria," 276, and "Assyrian Officials": 19; Fuchs, "Der Turtān": 62-64, 98-104; Karlsson, Relations of Power, 222 23; and Tallay Ornan, The Triumph of the Symbol, Pictorial Representation of Deities in Mesopotamia and the Biblical Image Ban, OBO 213 (Fribourg, 2005), 137.

${ }^{10}$ One note of caution is that the portrayal of authority may be quite different from the practice of it; in other words, the high officials may have indeed held a considerable amount of power, rivaling or even surpassing that of the contemporaneous kings, especially on the local stage. This paper provides a case study of how the officials portrayed themselves in text and image, but does not seek to conclude the debate about greater effects on the power of the Assyrian crown.

${ }^{11}$ The title sarru had traditionally been reserved for Ašsur himself, with the king as either the šangh-priest or išsakku ("viceregent") of the god: see Peter Machinist, "Kingship and Divinity in Imperial Assyria" in Text, Artifact, and Image: Revealing Ancient Israelite Religion, ed. Gary M. Beckman and Theodore J. Lewis (Providence, 2006), 153-59, and Stefan Maul's "Der assyrische König-Hüter der Weltordnung" (in Priests and Officials in the Ancient Near East, ed. K. Watanabe [Heidelberg, 1999], 214),
} 
placed a great emphasis on the role of the gods in their appointment and promotion to the throne in the first place. Divine election was described in royal inscriptions with a variety of expressions as to how the gods chose or called the king by name, leaving no doubt as to the king's legitimacy and right to sovereignty. ${ }^{12}$ Adad-nērārī III (810-783 BC), who was king during this contested period, called himself "the king in whose youth Aššur, king of the Igigu gods, chose and entrusted him with unrivalled rulership." 13 This sentiment shows continuity with Shalmaneser III, for instance, who wrote of his succession to the throne that "Aššur, the great lord, chose me in his steadfast heart (and) with his holy eyes and named me for the shepherdship of Assyria." ${ }^{14}$ Similarly, some inscriptions record the idea that the gods, if not Aššrur himself, called the name of the future king, as a recurring example from Ashurnașirpal II's demonstrates: "Aššur, the lord who called my name (and) who makes my sovereignty supreme, placed his merciless weapon in my lordly arms." ${ }^{15}$ What the kings that reigned during the period in question often added is the suggestion that their rulership was divinely predestined from long ago, as Adad-nērārī III was descended from the one "whose name Aššur called from of old," and Šamšī-Adad V was a king "whose name the gods designated from ancient times." 16 Most consistently attested, however, are the theophoric royal titles of $i s s a k$ A

which addresses the Assyrian king's role as the protector of the cosmic order in general, though much of his evidence comes from the later Sargonid kings. For the king's relationship with Aššur, see also Bradley Parker, "The Construction and Performance of Kingship in the Neo-Assyrian Empire," Journal of Anthropological Research 67/3 (2011): 365, with further bibliography, and Karlsson, Relations of Power, 75-77.

${ }^{12}$ See Karen Radner, "Assyrian and non-Assyrian kingship in the first millennium BC," in Concepts of Kingship in Antiquity, ed. Giovanni B. Lanfranchi and Robert Rollinger, HANEM 11 (Winona Lake, IN, 2010), 27, for "divine legitimation" as one of the three criteria for eligibility as the Assyrian king. For divine election in the period at hand, see Karlsson, Relations of Power, 78-80. This phenomenon is often called "divine appointment" or "divine rule" (Parker "Construction and Performance": 367, and Cyril John Gadd, Ideas of Divine Rule in the Ancient Near East [London, 1948]), but it should be noted that Assyrian kings were not themselves divinized.

${ }^{13}$ RIMA 3 A.0.104.1: 1-5.

${ }^{14}$ RIMA 3 A.0.102.1: 11, A.0.102.2: i 12-13

${ }^{15}$ RIMA 2 A.0.101.1: i 17-18, iii 118-119, A.0.101.2: 7-9, A.0.101.3: 29-31, A.0.101.23: 5-6, A.0.101.26: 14-16, A.0.101.51: 11-13.

${ }^{16}$ RIMA 3 A.0.104.1: 26-27 and RIMA 3 A.0.103.1: i 29-30, respectively.
Aššur, and šakin Enlil, "appointee of Enlil," which both have extensive histories in Assyrian titulary and are central to Assyrian kingship; one or both are always found when kings state their titulary or genealogy in their inscriptions. ${ }^{17}$

In contrast, the high officials do not take on these titles or, indeed, theophoric titulary as to any kind. Because these titles were divinely granted, it logically follows that officials would abstain from using the language of theophoric royal titulary not only for political reasons, but also out of respect (or fear) of the gods. ${ }^{18}$ The high officials also avoided "secular" royal titles such as "king," even though some officials in the Middle Assyrian period, who were placed in control of the western territories, called themselves "king of Hanigalbat." ${ }^{\prime \prime}$ At first glance, Šamšīilu seems to overstep his appropriate titulary, since he does not

${ }^{17}$ A division between "religious" and "secular" royal titles was made by Barbara Cifola in her survey of Assyrian royal titulary (Analysis of Variants in the Assyrian Royal Titulary from the Origins to Tiglath-Pileser III [Napoli, 1995], 3-5). Vladimir Sazonov prefers to call titulary that mentions gods "epithets and titles with theophoric elements," though he excludes titles that reference temple construction from this category (Die Assyrischen Königstitel und-Epitheta vom Anfang bis Tukulti-Ninurta I und seinen Nachfolern, SAAS 25 [Helsinki, 2017], 31). This paper uses the category "theophoric" instead of "religious" titulary to avoid confusion with titles that may have a religious character but do not mention gods (such as Šamšī-Adad V as the "shepherd of shrines," RIMA 3 A.0.103.1: i 27). For a discussion of the titles at hand, see Cifola, Titulary, 8-9, 13, 19, and charts nos. 1-13, and Sazonov, Königstitel, 32, 34-36, 105-107. Kings during the period in question (823-745 BC) that used these titles were Šamšì-Adad V, Adadnērārī III, and Aššur-dān III.

${ }^{18}$ Power at the officials' level was also divinely endorsed, as all authority was mediated through the gods, and the officials did invoke deities as supporters in their inscriptions. Divine election to office, however, could presumably not translate to kingship without the gods' consent, and so theophoric royal titles could not simply be appropriated. The process by which officials were given their positions is likewise not traditionally discussed in Assyrian royal inscriptions.

${ }^{19}$ A recent discussion of Hanigalbat in the Middle Assyrian period is given in Beate Pongratz-Leisten, Religion and Ideology in Assyria, SANER 6 (Boston, 2015), 157-66. See also Frederick Mario Fales, "'Hanigalbat' in the Early Neo-Assyrian Royal Inscriptions: A Retrospective View," in The Ancient Near East in the 12th-10th Centuries BCE: Culture and History. Proceedings of the International Conference held at the University of Haifa, 2-5 May, ed. Gershon Galil et al., AOAT 392 (Münster, 2010), 112-18. Fales argues that these officials were "connected to the ruling dynasty of Assur," and were usually called sukkallu rabi' $u$, while only a few were called sar $(m \bar{a} t)$ Hanigalbat in addition, and the title itself is rarely attested. Fales suggests (ibid., 117 n. 100) that "the title sarru applied to Hanigalbat/Hani-Rabbat, far from being a purely residual denomination of ideological worth as hitherto believed, 
include the king's name and expands his titles, adding several other administrative and military roles to turtānu, his primary and original position:

the field marshal, the great herald (nāgiru rabû), [the administrator of] temples ([ satam ékurr] $\bar{a} t i)$, chief of the extensive army (rab ummanni rapsii), governor ( $s \bar{a} \bar{a} p i r u)$ of the land Hatti (and) of the land of the Guti and all the land Namri, conqueror of the mountains in the West, who lays waste $[\ldots]$, who overthrows the lands Musku and Urartu, who pillages its people, who devastates the lands Utû, Rubû, Hadalu, (and) Labdudu, who defeats them. ${ }^{20}$

These extended titles are not unique; they are also found on a stele from Assur that belonged to Bêl-luballit, an official under Shalmaneser III, so they were still within established bounds for officials. ${ }^{21}$ Overall, the officials in this period kept only their original titularies or acknowledged their increased influence by using extended political and military titles, but not claiming higher ones.

In contrast to Šamšĩ-ilu's inscription, Bēl-Ḩarranbēlì-ușur's stele includes only a brief title and mentions the king's name: "Bēl-Ḩarran-bēlī-ușur, palace herald of Tiglath-pileser (III), king of Assyria." ${ }^{22}$ While scholars have remarked that it is unusual for an official's name to precede the king's in an inscription, this sequence is actually consistent with royal-type dedicatory objects and cylinder seals, which comprise half of the corpus of texts by high officials. ${ }^{23}$ The absence

might be viewed as tied to the special needs of the named area, such as to require an 'extraordinary' administration."

${ }^{20}$ RIMA 3 A.0.104.2010: 8-11.

${ }^{21}$ RIMA 3 A.0.102.2002: 1-10.

${ }^{22}$ RIMA 3 A.0.105.2: 9. Tiglath-pileser III's name seems to be a later addition, as initially the inscription named Shalmaneser IV as the reigning king (RIMA 3: 241), meaning that Bēl-Harranbēlì-ușur had been in office prior to 772 and until at least (or again in) 741 , when he was named as eponym. This suggests that he was probably at an advanced age by that time (PNA 1/II: 301).

${ }^{23}$ See, for instance, RIMA 3 A.0.104.2003, A.0.104.2004, A.0.104.2009, A.0.104.2015-17. Other objects omit the king's name (i.e., RIME 3 A.0.104.2006, A.0.104.2013-14), or list the official as subordinate to another official instead of directly to the king (see A.0.104.2005, A.0.104.2008). Only rarely does the king's name appear before the official's (see the dedication in A.0.104.2002: 8-10). Editions of the cylinder seals of the officials are given in Kazuko Watanabe, "Neuassyrische Siegellegenden," Orient 29 (1993): 109-29. Jamie Novotny (pers. comm.) notes that this order is typical of the "servant seal" format starting in the second millennium; see examples from the reign of Šamšì-Adad I of theophoric titulary in the officials' inscriptions and the reliance on traditional, non-royal secular titles suggests that the high officials were not overtly styling themselves as having divinely-granted authority that was otherwise reserved for kings.

\section{Divine Endorsement on Campaign}

With regard to divine endorsement and support on campaign, Šamšīilu's lions preserve a fairly standard royal-type campaign narrative, but a few points betray the reality that the author was not, in fact, the king. In royal inscriptions, Assyrian campaigns were normally undertaken at the behest and with the help of the gods, which was expressed in diverse ways, before, during, and even after the campaign. Šamšì-Adad V, for instance, credited the "weapons of Aššrur" and the "victories of Aššur, my lord" before his own "strong warfare" 24 and "praises of [Šamšī-Adad V's] heroic deeds," 25 respectively, indicating the god's primary role in achieving military victory. Adad-nērārī III, similarly, described himself as the one "who campaigns with the support of Ašsur, his lord, and subdues the princes of the four quarters." 26 The kings also invoked the oft-attested claim that the "awesome brilliance (melammu) of Aššur, my lord" frightened the enemy into submission or flight. ${ }^{27}$ Divine support was not restricted to Aššur-although he is found in this capacity more consistently than other gods are-as demonstrated by an example from Adad-nērārī III's inscriptions, which include the royal title "attentive prince whom the gods Aššur, Šamaš, Adad, and Marduk assisted so that he extended his land." 28

(RIMA 1 A.0.39.2003-2023) and from reigns throughout the Old Babylonian period, see RIME 4, passim. Occasionally, the king's name is mentioned first (see, for instance, RIMA 1 A.0.39.20032006, RIME 4 E4.5.1.2002-2004, E4.5.3.2001-2007), which is more consistent with the Sargonic and Ur III servant seals: see for example RIME 2 E.2.1.4.2009 (Narām-Sîn), 2011-16 (Šar-kali-šarrī) and RIME 3/2 89 E3/2.1.1.2001 (Ur-Nammu), E3/2.1.2.69-70, 2020-23, 2028-29 (Šulgi).

24 "I marched to the land of the Medes. They took fright in the face of the angry weapons of Aššur and of my strong warfare, which have no rival, and abandoned their cities" (RIMA 3 A.0.103.1: iii 27-30).

25 "I made my colossal royal statue (and) wrote thereon the victories of Aššur, my lord, praises of my heroic deeds, and all the things which I had achieved in the land Nairi" (RIMA 3 A.0.103.1: iii 20-24).

${ }^{26}$ RIMA 3 A.0.104.8: 4-5.

${ }^{27}$ See RIMA 3 A.0.103.1: ii 42-46 and A.0.104.8: 17-18.

${ }^{28}$ RIMA 3 A.0.104.1: 16-18. 
The statements that military action is undertaken ina qibit ("by the command") of the gods, or with ilānu tiklu'a ("the gods who support me") are particularly common phrases in the kings' inscriptions. Šamšî-Adad V writes:

At that time I spread over the entire land Nairi like a net. The land of Assyria, which (stretches) from the city Paddira of the land Nairi to the city Kār-Shalmaneser, which is opposite Carchemish, from the city Zaddi on the border of the land Akkad to the land Enzi, from the city Aridu to the land Suhi-(this area) by the command of the deities Aššur, Šamaš, Adad, (and) Ištar, the gods who support me, bowed down at my feet as though they were footstools. ${ }^{29}$

The gods are given full credit for the success of the campaign. Adad-nērārī III, explicitly placing himself in Šamši-Adad V's lineage, likewise invokes the gods in this role: "The kings of the extensive [land Hatti] who, in the time of Šamšn-Adad (V), my father, had become strong and withbeld their [tribute] - by the command of Aššrur, Marduk, Adad, Ištar, the gods who support me, (my) awesome radiance overwhelmed them and they submitted to me." 30

Šamšĩ-ilu prefaces his narrative in a similar way, starting with his claim that he led the soldiers ina qibit Aššur and Mullissu; however, Šamšĩ-ilu omits the statement ilānu tiklü'a: "By the command of the father, Aššur, the great lord, and the lofty mother of Ešarra, foremost among the gods, the goddess Mullissu, Šamši-ilu, the field marshal, the great herald, [the administrator of] temples, chief of the extensive army, put a strong force of soldiers into those mountains." ${ }^{31}$ Describing the gods as supporters represents a close mutual relationship between god and king to which officials are not entitled. Also unusual is the fact that the goddess Mullissu does not appear in this context otherwise - the contemporary and earlier kings usually list a combination of Aššur, Šamaš, Adad, Ištar, and occasionally Marduk as their commanding gods. Mullissu's pairing with Aššur and her epithet, "lofty mother of Ešarra," referring to Aššur's temple in the city Assur, may thus not indicate pretensions of divine imperatives meant for royalty, but rather the endorsement of Assyria itself, mediated through the religious

\footnotetext{
${ }^{29}$ RIMA 3 A.0.103.1: ii 4-16.

${ }^{30}$ RIMA 3 A.0.104.6: 13-17.

${ }^{31}$ RIMA 3 A.0.104.2010: 13-15.
}

capital and the recognized king. Thus, the official does not claim that the traditional campaign gods were at his side in combat, but rather locates the divine command as coming from the symbolic center of Assyria. ${ }^{32}$

In the campaign narrative that follows the invocation of Aššur and Mullissu, Šamšīilu compares himself to a storm: "with the great roar of drums (and) weapons at the ready which reverberate terrifyingly, he rushed forth like a terrible storm (imbullis). He let fly the stormy steeds, harnessed to his chariot, against him (Argištu) like the Anzu-bird (anzânišs) and defeated him." ${ }^{33}$ Similes invoking a vicious storm are also found in the kings' inscriptions, and a few of Ashurnasirpal II and Shalmaneser III's texts even include the simile of the $a n z \hat{u}$-bird, as Šamšn-ilu's does. ${ }^{34}$ There is, however, an important difference in how the storm is invoked; namely, Šamšĩ-ilu describes his actions as being imbullis, "like a terrible storm," while kings liken themselves to the storm god Adad. Šamši-Adad V, for instance, records that "at that time I thundered like the god Adad (GIM d'šKKUR), the thunderer, over (the people in the area) from Mount Kullar, the mighty mountain, to the sea of the west." ${ }^{35}$ An inscription of Ashurnasirpal II provides both similes, in that the king claimed that "on the second day, before sunrise, I thundered against them like the god Adad-of-the-Devastation (GIM ${ }^{\mathrm{d}}$ IšKUR šá Gìr.BAL) (and) rained down flames upon them. With might and main

\footnotetext{
32 The Assyrian political capital had moved to Calah under Ashurnasirpal II, but Assur remained the religious center.

${ }^{33}$ RIMA 3 A.0.104.2010: 15-17.

${ }^{34}$ Ashurnașirpal II and Shalmaneser III used the Anzû-bird simile to describe their troops, in the former's inscriptions with the phrasing "with might and main my combat troops flew against them like the $a n z \hat{u}$-bird" (for example in RIMA 2 A.0.101.1 ii 106-107, though Grayson tends to translate as "the Storm Bird"), and the latter's "my soldiers flew up against them like the $a n z \hat{u}$-bird" (RIMA 3 A.0.102.5 iii 5). Anzû is associated with the warrior god Ninurta, who famously defeats him in the Epic of $A n z \hat{u}$ and with whom the Assyrian king is eventually identified (Amar Annus, The God Ninurta in the Mythology and Royal Ideology of Ancient Mesopotamia, SAAS 14 [Helsinki, 2002], 93-101). Dalley, "Shamshi-ilu," 85, suggests that "in describing how the viceroy defeated his enemy 'like Anzu,' the text implies that Shamsi-ilu played a mythological role in gaining control over destinies by subduing cosmic chaos and primeval wickedness," a responsibility generally ascribed to the Assyrian king (Annus, The God Ninurta, 96). Instead of taking on kingly characteristics through the reference to Anzû and thus to Ninurta, Jamie Novotny, pers. comm., has suggested that the subordinate nature of Ninurta to Ašsur's command may have been used to parallel Šamšĩ-ilu's obedience to the Assyrian king.

${ }^{35}$ RIMA 3 A.0.103.1: iii 67-69.
} 
my combat troops flew against them like the Storm Bird (GIM anzêe)." ${ }^{36}$ It is interesting to note that the kings used the standard kīma (GIM) while Šamšĩ-ilu instead opts for the rare terminative-adverbial ending $-i s^{2}{ }^{37}$ Kings sometimes compared themselves to other gods in their inscriptions as well, and one can postulate that this was a royal privilege that no official would dare to claim. ${ }^{38}$ Thus, the motif of the storm and the Anzû bird in Šamšìilu's campaign narrative is a clear reference to the language used in royal inscriptions, but is slightly modified to show the might of the official without overstepping the boundaries of his office.

\section{Invocations of Gods}

For the introductory invocation of gods, a well-established trope in royal inscriptions, Šamšĩilu chose a list of major gods and epithets that is mostly unremarkable for this period:

God Ašsur, great lord, king of the gods, [who] decrees destinies; god Anu, mighty, foremost, ancestor of the great gods; god Enlil, father of the gods, lord of the lands, who makes sovereignty great; god Ea, the wise, king of the apsi who grants wisdom; god Marduk, sage of the

${ }^{36}$ RIMA 2 A.0.101.17: iv 70-74. See also Shalmaneser III RIMA 3 A.0.102.5: iii 2-3 "I slaughtered the extensive Guti like $(k \bar{\imath})$ the god Erra. I thundered like (kima) the god Adad, the devastator."

${ }^{37}$ On the $-i s^{2}$ ending, Wolfram Von Soden (GAG: 110) wrote that royal inscriptions are the genre of later texts in which the ending is often attested, and that "er seit 1300 dort auch als Vergleichskasus verwendet wird" due to its use as an adverbial suffix. It is noteworthy here because John Huehnergard writes that it "corresponds semantically to the preposition ana plus the genitive" (i.e., not to kima) and that "on nouns, -is is no longer a productive morpheme by the $\mathrm{OB}$ period; its occurrence is restricted to a relatively small group of nouns, and, apart from a few frozen expressions, almost exclusively to poetry and some personal names" (John Huehnergard, A Grammar of Akkadian (Third Edition) [Winona Lake, IN, 2011], 311).

${ }^{38}$ Winter notes that "god-like properties and resemblances of (images of the) ruler had to have been recognizable by viewers" (Irene Winter, "Touched by the Gods: Visual Evidence for the Divine Status of Rulers" in Religion and Power: Divine Kingship in the Ancient World and Beyond, ed. N. Brisch, OIS 4 [Chicago, 2008], 85-86). Other gods to whom kings compared themselves include Erra, see n. 36 above. The comparison of the king's onslaught to Adad re-emerges under Sennacherib as well, for instance in RINAP 3/1 22: v 74-75, in which he claimed: "I roared loudly like a storm (and) thundered like the god Adad (GIM dIšKUR) against all of the troops of the wicked enemies." gods, lord of omens, commander of all; god Nabû, scribe of Esagil, possessor of the tablet of destinies of [the gods], who resolves differences; [god] Sîn, luminary [of heaven and underworld], lord of the lunar disk, who illuminates the firmament; goddess Ištar, mistress of battle [and] strife, overthrower of the fierce; goddess Gula, the great chief physician, wife of the hero of the gods, the mighty son of the god Enlil. ${ }^{39}$

But two details about this invocation are striking. The first is that, in the inscriptions of kings, the phrase "who make(s) my sovereignty (sarrūtìya) great" is a very common epithet of the gods. Enlil's epithet in Šamšĩ-ilu's invocation is similar but instead reads, "who makes sovereignty ( sarrūtu) great," without indicating a personal pronoun..$^{40}$ This is a small adjustment with larger implications, supporting the hypothesis that Šamšĩ-ilu mimics the language of the king, but recognizes that his office does not include sovereignty over Assyria.

Furthermore, the invocation list ends abruptly, as did the list of commanding gods in the campaign narrative mentioned above. In the royal inscriptions of the early Neo-Assyrian period, the space between the invocation and the name and titulary of the king always contains an epithet for the invoked gods as a group and, in all but one case, a statement of the king's divine endorsement and election to kingship. Several of Shalmaneser III's texts, for instance, conclude the invocation list with statements such as "the great gods, who love my sovereignty, who have made great my dominion, power, and leadership, (who) have richly established for me my honorable name (and) my lofty command over all lords." ${ }^{31}$ A section of this type is omitted in Šamšĩ-ilu's inscription, and he did not qualify the list of gods invoked as having any special relationship to him or his office.

Bēl-Hुarran-bēlì-uṣur's text begins with a more unusual invocation, the only one in the early NeoAssyrian period to omit Ašsur and to begin instead with Marduk:

${ }^{39}$ RIMA 3 A.0.104.2010: 1-8. Gula is perhaps the most unusual member of the list.

40 "Sovereignty" is here written šarrüti (MAN- $\hat{u}$ - $[t i])$. One should note that the final $-t i$ is not preserved but the restoration is nonetheless sound, since the $\dot{u}$ is preserved. The form sarritutya is written MAN- $t i-a$ or MAN- $t i-i a$, "my (i.e., the king's) sovereignty" in royal inscriptions, and there are no instances in which sarrūtu plus any personal pronoun is written with $-\hat{u}$ - (or any other sign) before the $-t i$ -

${ }^{41}$ For example, RIMA 3 A.0.102.2: i 3-4. 
God Marduk, great lord, king of the gods, who holds the circumference of heaven and underworld, who populates cities (and) establishes sanctuaries, who supervises all the shrines of the gods; god Nabû, scribe of the gods, who grasps the holy tablet stylus, who carries the tablet of the destinies of the gods, who provides for the Igigu and Anunnaku gods, who continually gives food rations (and) thereby grants life; god Šamaš, light of the lands, judge of all cities (and) protector of the (four) quarters; god Sin, luminary of heaven and underworld, who is endowed with lofty horns and clothed in brilliance; bright goddess Ištar-kakkabī, the goddess Inninna, whose forgiveness is good (and) who receives prayers. ${ }^{42}$

The absence of Ašsur could prompt the argument that Bēl-Ḩarran-bēlì-uṣur rejected the Assyrian king's authority, although Aššur is found later in the cursing formula. It is indeed quite surprising to see the absence of the Assyrian god par excellence in the invocation; Marduk, on the other hand, is a fairly common sight in Assyrian inscriptions of this period. The reason behind omitting Aššur, however, may not have been the official distancing himself from Assyria, but may rather have had to do with the contents of the stele, in particular the passages about the construction of a new city.

\section{City (Re)Building and Construction Reports}

Bèl-Ḩarran-bēlì-ușur's stele records the building of a city that he named Dūr-Bēl-Huarran-bēlì-ușur, after himself. ${ }^{43} \mathrm{He}$ claimed that this action was endorsed by, presumably, the gods listed in the invocation, since it ends by identifying the named gods as "all great gods

${ }^{42}$ RIMA 3 A.0.105.2: 1-8. Inninna ( ${ }^{\mathrm{d}}$ in-nin-na) is a hapax legomenon in the Neo-Assyrian material; Grayson equates this deity with Inanna in his edition of the text.

${ }^{43}$ Newly-constructed or newly-conquered (royal) cities were often named on the pattern Dūr-PN or Kār-PN; see Beate Pongratz-Leisten, "Toponyme als Ausdruck assyrischen Herrschaftsanspruchs," in Ana šadî Labnāni lū allik: Beiträge zu altorientalishen und mittelmeerischen Kulturen. Festschrift für Wolfgang Röllig, ed. Beate Pongratz-Leisten, Harmut Kühne, and Paolo Xella, AOAT 247 (Neukirchen, 1997), for the use of this convention in Assyrian imperialism. A recent survey of Neo-Assyrian place names, including those that begin with Dūr- and Kār-, is given in Ariel M. Bagg, Die Orts- und Gewässernamen der neuassyrischen Zeit. Teil 2: Zentralassyrien und benachbarte Gebiete, Ägypten und die arabische Halbinsel, RGTC 7/2 (Wiesbaden, 2017). who heed his petitions, his allies, his lords," ${ }^{44}$ and it is the ilānu rabûtu, "great gods," who instruct the official to build his city:

Bēl-Ḩarran-bēlī-ușur, palace herald of Tiglathpileser (III), king of Assyria, worshipper of the great gods - these mighty lords gave me instructions and at their exalted command and with their firm assent I set out to build a city in the desert, in the wasteland, (and) completed it from top to bottom. I constructed a temple and founded therein a shrine for the great gods. I laid its foundation as firm as the mass of a mountain (and) established its base for eternity. I made it known among the people that its name was Dūr-Bēl-Ḩarran-bēlì-ușur and made a good road to it. ${ }^{45}$

Not calling Aššur by name may indicate that BēlHarran-bēli-ușur wanted to avoid the conventions found, for example, in Ashurnașirpal II's accounts of rebuilding Calah. Ashurnașirpal II's inscriptions made it clear that the gods, especially Aššur, played a central role in the transformation of Calah into the king's new capital. The king wrote that

Ašsurur, the great lord, cast his eyes upon me and my authority (and) my power came forth by his holy command. Ashurnașirpal, the king whose strength is praiseworthy, with my cunning which the god Ea, king of the apsî, extensively wise, gave to me, the city Calah I took in hand for renovation. ${ }^{46}$

The king recorded the invitation of the gods into the palace, his new seat of power, and even the dedication of the city itself to Aššur. ${ }^{47}$ In contrast, Bēl-Huarranbēlī-uṣur described his relationship to the gods only generally, calling himself one who pāliḩ ilāñ̄ rabûti "venerates the great gods," and abstaining from specifying for which deities he built temples in his city. Thus, Bēl-Ḩarran-bēlī-uṣur may have omitted Aššur

${ }^{44}$ RIMA 3 A.0.105.2: 8.

${ }^{45}$ RIMA 3 A.0.105.2: 9-14.

${ }^{46}$ RIMA 2 A.0.101.30: 20-23.

${ }^{47}$ RIMA 2 A.0.101.30: 102-105 and A.0.101.33: 27'. On the role of the gods in the creation of new political capitals, see Shana Zaia, "Divine Foundations: Religion and Assyrian Capital Cities," in As Above, So Below: Religion and Geography (Workshop at the 62nd Rencontre Assyriologique Internationale in Philadelphia, July 11-15, 2016), ed. Gina Konstantopoulos and Shana Zaia (Winona Lake, IN, forthcoming). 
in order to avoid using the conventions reserved for kings regarding their divinely-granted authority, specifically from Aššur, to create a new center of power or capital city.

A blessing formula at the end of a construction report is another standard feature in the Assyrian royal inscriptions. ${ }^{48}$ Traditionally, the blessing begins with a statement that beseeches the king's successors to maintain the building and the inscription recording its construction, promising divine favor in return. Two examples from the reigns of Shalmaneser III and Adad-nērārī III demonstrate that the addresses to later princes are almost identical: "may a later prince ( $r u b \hat{u}$ ark $\hat{u})$ restore its weakened (portions) and return my inscription to its place" 49 and "when this temple becomes old (and) dilapidated may a later prince (rubî ark $\hat{u}$ ) restore its ruined areas (and) return my inscription to its place," respectively. ${ }^{50}$ Bēl-Huarran-bēlì-ușur's inscription deviates from the convention by addressing the blessing not to a future king but to "whichever later one (mannu arkî) whom the gods Aššur, Šamaš, Marduk, and Adad name to be in charge of (um"aru) the land for (its) benefit" meaning, presumably, his own replacement. ${ }^{51}$ The divinely-granted authority is likewise circumscribed, restricted to some-

${ }^{48}$ See Kyle Greenwood, "The Hearing Gods of the Assyrian Royal Inscriptions," JANER 10/2 (2010): 211, and Karlsson, Relations of Power, 216-17. Additionally, see Jamie Novotny, "Temple Building in Assyria: Evidence from Royal Inscriptions" in From the Foundations to the Crenellations: Essays on Temple Building in the Ancient Near East and Hebrew Bible, ed. Mark J. Boda and Jamie Novotny, AOAT 366 (Münster, 2010), for the importance of the divine with regard to temple rebuilding.

${ }^{49}$ RIMA 3 A.0.102.39: 11-12.

${ }^{50}$ Siddall, Adad-nīrārī III, 194-95 (Tell Šaih Hamad Stele).

${ }^{51}$ RIMA 3 A.0.105.2: 17-18. Mattila (Magnates, 162) notes that, while there is record of the "Land of the Palace Herald," which was situated on the northeast border, these attestations stem from Sargon II's reign, and so one cannot assume that this is the land to which the official refers in his stele. The verb wâru is not typically used in the blessing formulae in royal construction reports (though it is sometimes found in campaign reports), but it is the same verb that Bēl-Ḩarran-bēlī-uṣur uses in line 10 ("these mighty lords gave me instructions [uma"erunnima]") before he begins his description of the construction of his city. In terms of protections that are addressed to non-royal persons, one can compare this with Ashurnașirpal II's safeguarding of a menagerie of animals that he collected, which begins with the royal successors, but includes several other categories of officials and non-royal figures. Ashurnașirpal II writes: "O later prince among the kings my sons whom Aššur calls, or later people, or vice-chancellor, or noble, or eunuch-you must not despise (these animals). Before Aššr may these creature(s) live!" (RIMA 2 A.0.101.2: 38-39). Here, the term one in charge of the territory under Bēl-Harran-bēlīusurur's control, which is done only for its "benefit" (damiqtu), rather than making claims of "rulership" of the land..$^{52}$ This is the only blessing in the royal-type corpus of this period, but the directive to "a later one" rather than to "a later prince" is consistent in all of the cursing formulae found as well. ${ }^{53}$

Cursing formulae are similarly common after building accounts, often but not always paired with blessings, and serve the same function of ensuring the successors' maintenance of both the construction work and the inscription detailing it, threatening divine retribution for those who ignore this task. ${ }^{54}$ The curse that follows Bēl-Harran-bēlì-ușur's blessing in the Tell Abta stele, for instance, reads "as for the one who alters (munakkir) my inscription or name, may the gods Aššur, Šamaš, Marduk, (and) Adad, the great gods, not have mercy upon him, to his utter destruction." ${ }^{55}$ The change in convention may also be related to the fact that many, if not all, of these officials were eunuchs, and thus could not have descendants to inherit their office. ${ }^{56}$ Although Bēl-Harran-bēlī-ușur does not have the title $\bar{s} a$ rési $i$, found with several other officials, ${ }^{57}$ he has been identified as one because he was portrayed beardless on his stele.

\section{Iconography on the Steles: The ubāna tarāṣu Pose}

The relief on the Tell Abta stele depicts Bēl-Harranbēlī-ușur in a pose traditionally associated with kings, called the ubāna tarāșu, or "finger pointing," pose, in which the king gestures towards divine symbols near

\footnotetext{
for "later people," nišu arkûtu, is notably similar to Bēl-Huarranbēlī-ușur's mannu arkû.

${ }^{52}$ Meaning "good fortune," "blessing," or "a good fate" (CAD D s.v. damiqtu s. 1 and 2).

${ }^{53} \mathrm{~A}$ few inscriptions from this period other than the Tell Abta stele contain curses, and they are equally vague: the joint inscription of Adad-nērārī III and Šamšīilu reads "whoever afterwards speaks ill of the terms of this stele, and takes by force this border from the possession of Ataršumki, his sons, or his grandsons; and destroys the written name (and) writes another name" (RIMA 3 A.0.104.2: 13-16). Bēl-tarși-ilumma begins the formula with "whoever you are, after (me)" (A.0.104.2002: 12). A.0.104.7: 21 is written by Adad-nērārī III and directed towards high officials ("whoever erases one name from these names") but uses šá instead of mannu arkû.

${ }^{54}$ See Karlsson, Relations of Power, 216-17 for an overview of this phenomenon in this period.

${ }^{55}$ RIMA 3 A.0.105.2: 29-30.

${ }^{56}$ Radner, "Royal Decision-making," 359-61.

${ }^{57}$ See n. 4 , above.
} 
his head. ${ }^{58}$ This image was used by the contemporary kings Šamšī-Adad V and Adad-nērārī III, and would continue to be the standard pose depicted in Assyrian steles until Sennacherib's reign. ${ }^{59}$ Bēl-Harranbēlì-ușur's relief mirrors the royal iconography quite closely, and T. Ornan has suggested that the official's use of this trope is evidence of the king's reduced power. ${ }^{60}$ Yet, as with the written conventions, there are indications of a difference in status from the kings. The official is portrayed beardless, a telltale sign of a eunuch, and he does not have the trademark headdress of an Assyrian king as seen in the royal reliefs. ${ }^{61}$ His

${ }^{58}$ Ursula Magen, Assyrische Königsdarstellungen: Aspekte der Herrschaft, BaF 9 (Mainz am Rhein, 1986), 50, and Mattila, Magnates, 31 . The pose is attested already in the Akkadian period (Claudia Fischer, "Die Bildsymbolik der Assyrer in der akkadischen Tradition," AoF 27/2 [2000]: 309). Divine symbols and their correlation to specific deities continue to be the source of some debate but many have identified the ones on this stele as including Marduk, Nabû, Sîn, Šamaš, and Ištar, corresponding with the gods in the invocation. O. Aytuğ Taşyürek ("Some New Assyrian Rock-Reliefs in Turkey," Anatolian Studies 25 [1975]: 176) identifies a parallel depiction that adds Aššur's symbol in the Karabur reliefs in Hatay, Turkey. According to Ornan (Triumph, 139), “on monuments dated to the reigns of Ashurnasirpal, Shalmaneser III and ShamshiAdad V, there are usually five symbols shown in front of the gesturing king: a horned mitre, a star, a winged disc, a crescent moon and a lightning bolt. At times, the seven-dot emblem representing the sebetti is added, for example, on Ashurnasirpal's Banquet Stela commemorating the inauguration of the North-West palace . . . an addition of two divine symbols to the above-mentioned five emblems is attested on stelae dated to Adad-nirari III: the marru spade of Marduk and the stylus of Nabu."

${ }^{59}$ Ibid., 134-35. See the Šamšī-Adad V stele from Calah and Adad-nērārī III's Tell al-Rimah stele (RIMA 3: 180-181, 209). A fragmentary stele of Adad-nērārī III from Dūr-Katlimmu depicts the king in this pose as well, see Karen Radner, "The Stele of Adadnērārī III and Nergal-ēreš from Dūr-Katlimmu (Tell Šaih Hamad)," AoF 39 (2012): 268, including images.

${ }^{60}$ Ornan, Triumph, 137.

${ }^{61}$ See Mattila, Magnates, 31, 132, and Ornan, Triumph, 137. On the distinctions between royal and non-royal headdresses, see Julian E. Reade, "Fez, Diadem, Turban, Chaplet: Power-Dressing at the Assyrian Court," in Of God(s), Trees, Kings, and Scholars. Neo-Assyrian and Related Studies in Honour of Simo Parpola, ed. Mikko Luukko, Saana Svärd, and Raija Mattila, Studia Orientalia 106 (Helsinki, 2009). Illustrative here is Reade's observation (p. 262) regarding the fez that "courtiers had worn the fez in the Middle Assyrian period, but are no longer seen to do so in the ninth century, when there is a greater visual divide between them and the king ... some of the most important of these men wore a turban which was usually wound round the head in a distinctive fashion, so that the top of the hair was covered at the back but not at the front." Reade (ibid., 251-52) further writes that "we could postulate a ninth-century rule, not strictly observed on the sculptures, whereby turbans were reserved for a few eunuchs of very high status such as clothing also conforms to typical Assyrian dress, not to that of royalty. ${ }^{62}$ In addition, rather than holding the royal scepter, Bēl-Hुarran-bēlī-uṣur's non-pointing hand is empty. This gesture is called $u p n \bar{a}$ pet $\hat{u}$, or "opening of the fist," which is taken to denote supplication. ${ }^{63}$ The kings, on the other hand, carry royal scepters or maces. ${ }^{64}$ These characteristics are consistent with figures that have been identified as eunuchs or courtiers in cylinder seals and royal reliefs. ${ }^{65}$ One can compare the absence of the royal scepter to the image of another official, which appears not on a stele but on a rock relief in Cudi Dağ; Ornan writes that "the figure holds what seems to be a large sword in his left hand, instead of the ceremonial mace carried by the king in royal monuments." ${ }^{66}$ In terms of depictions of Šamšĩ-ilu, it has been suggested that he is portrayed on the Antakya Stele, but unfortunately the top half is broken away, and so this cannot be confirmed ${ }^{67}$ As with the adjusted textual conventions, the high official

the turtānu, or for royal siblings," but that depictions of officials wearing turbans are not extant for the period ca. 815-750. Thus, Bēl-Harran-bēlī-ușur does not appear with any type of headdress but is instead bare-headed, as courtiers and eunuchs of this time would be depicted at this time. For comparisons between figures wearing turbans and those with no headdresses, see ibid., Figs. 11 and 12 .

${ }^{62}$ Magen, Königsdarstellungen, 50.

${ }^{63}$ Ornan, Triumph, 37, writes that "the arm gesture, in which the worshipper raises his right arm, fist clenched with one finger pointing forward, while his left arm is extended toward the deity with its palm open, is the typical Assyrian gesture of supplication, portrayed in Neo-Assyrian imagery until the reign of Sennacherib," although she does not distinguish this from the depictions of $u b \bar{a} n a$ taras $u$ in which the figure holds something in his left hand.

${ }^{64}$ See the Šamšì-Adad V stele from Calah and Adad-nērārī III's Tell al-Rimah stele (RIMA 3: 180-81, 209; for images, see Ornan, Triumph, 272, and BM 118892).

${ }^{65}$ See, for example, the cylinder seal of Bēl-ašarēdu, overseer of the palace ( $r a b$ ekalli), which shows two unbearded figures making this gesture before the god and three divine symbols (Hayim Tadmor, "The Seal of Bel-Asharedu-A Case of 'Migration'," in Immigration and Emigration within the Ancient Near East. Festschrift E. Lipinski, ed. Karel van Lerberghe and Antoon Schoors, OLA 65 (Leuven, 1995), 347-52). See Ornan, Triumph, 137 for other examples.

${ }^{66}$ Ibid., 137 n. 418, with an image on p. 179.

${ }^{67}$ Karlsson, Relations of Power, 222, RIMA 3: 203. It is clear that the figure on the right is bearded, but the same cannot be concluded for the figure on the left. It does not appear that either figure is holding a scepter. For an image of the stele, see Veysel Donbaz, "Two Neo-Assyrian Stelae in the Antakya and Kahramanmaraş Museums," Annual Review of the Royal Inscriptions of Mesopotamia Project 8 (1990): 11. 
mimics a well-established royal trope, but does not cross the line into portraying himself as royalty.

\section{Conclusions}

While the changes in text and image are subtle, they are reflective of a careful attempt on the part of the high officials to avoid overstepping the sovereignty of the king or infringing upon the royal relationship with the gods. Any authority that the officials gained was still negotiated through the political hierarchy's traditional framework and representational boundaries. The royal-type inscriptions indicate that even the most standardized motifs could be adapted to reflect the new reality of the officials' increased power, also demonstrating a strong self-awareness behind the use of certain titles, epithets, and expressions. The small but significant changes discussed here can shed further light on this period, as well as the highly debated position of the officials. While not conclusive, the deliberateness of non-royal self-presentation demonstrated above could support the theory that these officials were not seeking to usurp royal power or rebel against the Assyrian king but rather that, while the circumstances may have allowed individual officials to have more de facto independence, they still recognized the ultimate and divinely-granted sovereignty of the Assyrian king. The evidence suggests that, despite the king's physical absence in the periphery of Assyria, the use of modified royal-type conventions allowed the officials to relay royal presence while representing their own authority within the established limits of the Assyrian hierarchy. 